\title{
The restoration of the wooden monument church Saint Parascheva from Crivina de Sus, a training for the interdisciplinary project team
}

\author{
Vladimir Obradovici ${ }^{1, *}$ \\ ${ }^{1}$ Politehnica Timişoara, faculty of Architecture and Urbanism, Piaţa Victoriei Nr. 2 Timişoara \\ 300006, jud. Timiş, România
}

\begin{abstract}
The restoration project of Saint Parascheva wood monument church, started in 2013 in Crivina de Sus village, from another project initiated by the association AsoP, to study the cultural landscape of the Faget Area, where the oldest wooden monument church in the Bant region in Romania is located. Studies commenced in 2013 have shown us that the wooden church is the central element of the landscape while at the same time being in a precarious state of preservation. In the next years, experimental studies on the monument and it's context, realised by specialists and students from areas related to restoration, followed. These investigations have initiated a restoration school that formed an interdisciplinary team for studying and planning restorations of the wooden churches in our region. In the summer of 2018 , the actual restoration of the church began, which is also a learning project for the team of restorers and volunteers.
\end{abstract}

\section{Background}

This article presents an ongoing research and education project started in 2013 in the village Crivina de Sus in the western part of Romania, where studies of the cultural landscape were carried out. This article presents only one small part of the process, that of the restoration of the wooden monument church of Saint Parascheva, having the purpose to present the interdisciplinary methodology adopted, and the results obtained until now.

The restoration project was started from another study, "The Cemetery as an Element in the Evolution of the Cultural Landscape" [1] that was carried out by the Landscape Association of Romania, western territorial branch.

These studies were conducted in teams of professionals, involving the fields of: history, anthropology, theology, architecture, urbanism and landscaping.

\footnotetext{
* Corresponding author: Vladimir Obradovici vladimir.obradovici@yahoo.com
} 

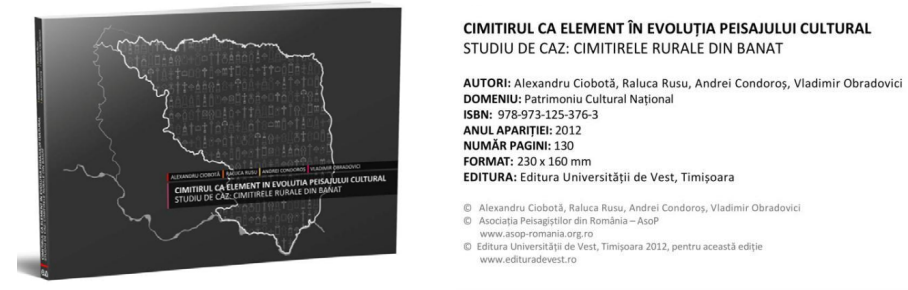

Fig. 1. The research of the rural cemeteries in Banat, from which the restoration project started (original)

In 2013, within the framework of the research: "The cemetery as an element in the evolution of the cultural landscape; recommendations for the protection of the character of the Romanian, Serbian and Ukrainian rural cemeteries in Banat" [1], we have decided to choose, on the basis of predefined criteria, a typical Romanian village, that preserves as much as authentic character as possible. So we reached the Făget Ethnographic area, the area of old Romanian communities, recorded from the Middle Ages, a hilly area that escaped the Habsburg colonization and partly the territorial systematization of the villages that was applied to other parts of the Banat region. [2]

Crivina de Sus is a typical valley village, located in the western part of Romania, which retains a few wooden vernacular households and the church of Saint Parascheva, the oldest still standing wooden church in Banat region (1676) [3]
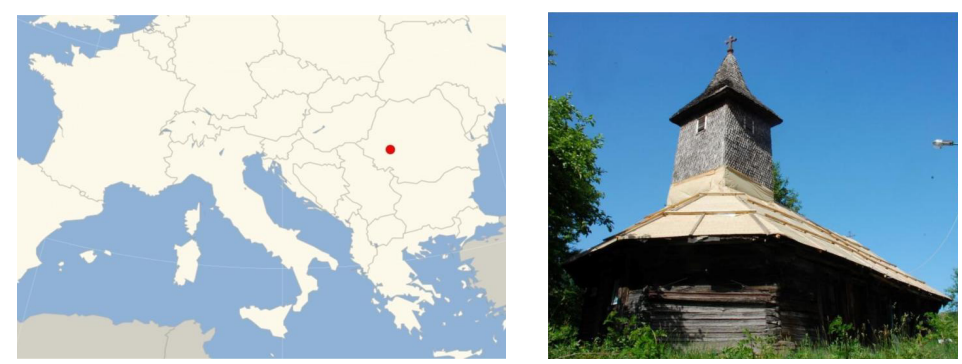

Fig. 2. Location of Crivina de Sus village / The church of Saint Parascheva (original)

\section{The project}

\subsection{3-2018 Crivina de Sus workshops}

We organised a first interdisciplinary workshop in the summer of 2013 attended by specialists from various fields related to our research subject, such as: anthropologists, theologians, artists, restorers, geographers, architects, urban planners, landscape architects and students from different fields such as: architecture, landscaping, restoration, theology and cultural studies.

In this workshop, the first research on the wooden church were carried out: measurements, photographic documentation and degradation studies. The findings showed us, the poor conservation status of the monument, which had major roof problems that caused infiltration of water inside, the bottom beams that were rotten and covered with earth and wall and tower structural deformations. 


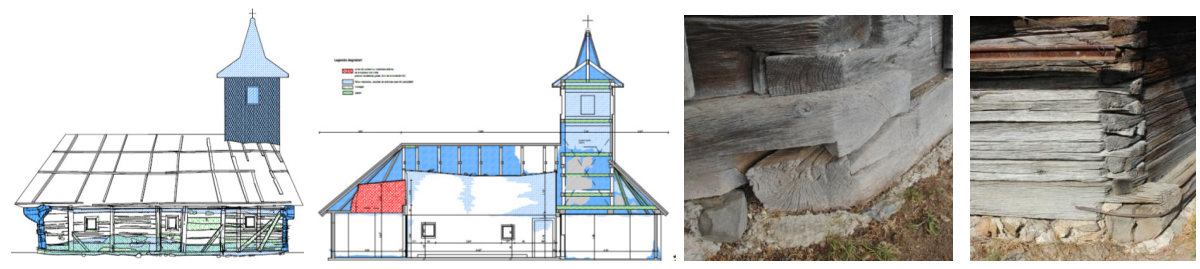

Fig. 3. A first decay survey, decay and structural problems (original)

After this first workshop we decided to continue the process of studying the wooden monument church in order to later save it.

The summer workshop in 2014 was organized similar to the previous year, and we continued the before started studies. A detailed survey of the church using the spatial axis method ("vagris") was carried out, through which we began to understand how the structure of the church and its components work together, as well as its structural and biological problems and deformations. In compare we realised also a photogrammetric survey of the interior and exterior of the church.
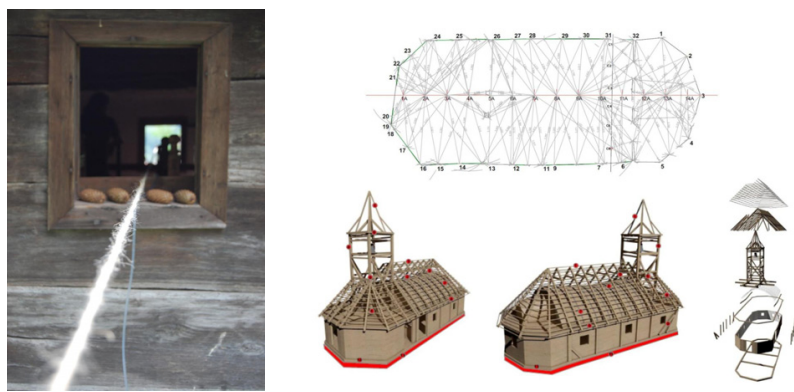

Fig. 4. Traditional survey using defined axes (vagris ) / $3 \mathrm{~d}$ model based on the traditional survey (original)
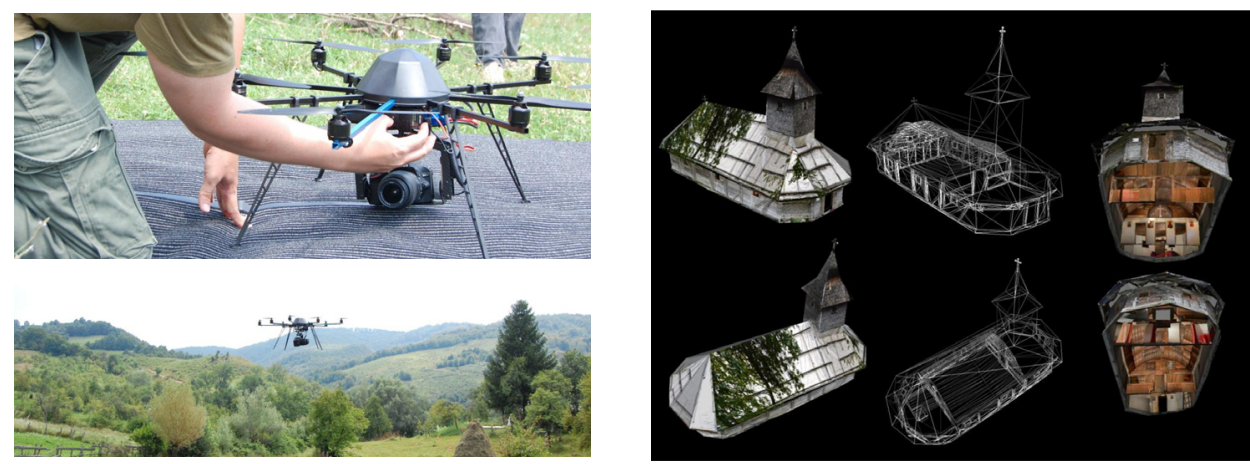

Fig. 5. Photogrammetric survey / $3 \mathrm{~d}$ model based on the photogrammetric survey (original)

We also invited a biologist (Mrs. Livia Bucsa), a known specialist in biological expertise of historical wood structures, resulting a first preliminary biological report of our church.

That year, the next step of the project was planned, to place a covering structure to protect our church. It had to meet more specific needs: the church had to be covered with a structure allowing the work space at the level of the roof and the tower at the time of the 
restoration, it had to be a totally reversible structure on the cemetery around the church, so no concrete foundations were alowed! The structure had to be easy to mount and dismantle to be easily moved after the restoration on another church that requires protection. Many types of covering structures were studied, and the most apropiat showed to be a tensile structure on metal posts that became a "landmark".

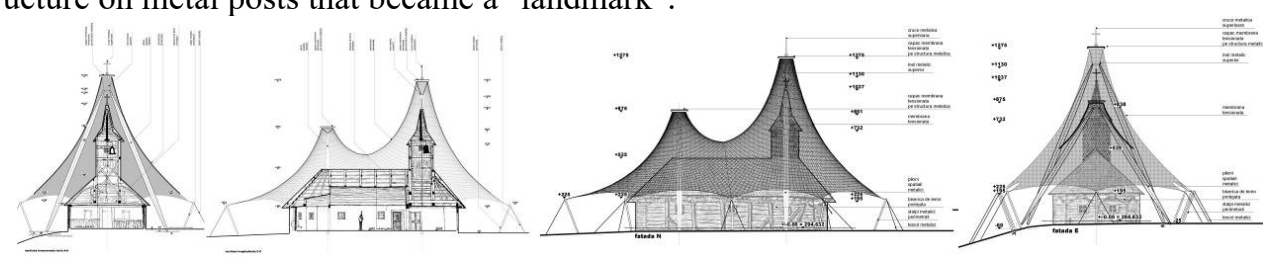

Fig. 6. The scaffold project (original)

In the summer of 2015 a new workshop was organised around the wooden church, where we began to study in detail the wooden elements of the church. One of the aims of the workshop was to survey in detail and make one analysis sheet for each element of the church.

In the winter of 2015 for three days (18-20 December 2015) the tensile scaffolding was mounted over the wooden church. The team of volunteers and specialists was formed an the structure was successfully placed. by ing. Dragoş Dumitrescu and two members of his company who produced the membrane, and ing. Radu Diaconovici and the team of his company who had previously installed the metal screwed foundations, Valeriu and Claudiu Armene, who raised with a crane the tense structure over the church and many other volunteers.
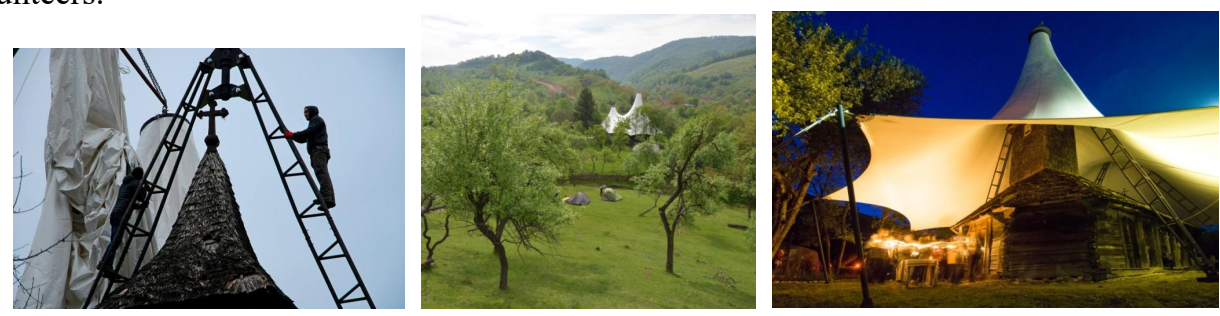

Fig. 7. The scaffold mounting / the ready mounted scaffold (original)

Following the scaffolding and the removal of the old degraded shingles, at the summer workshop in 2016, we had access to the upper part of the church, and we were able to record and draw up analytical charts for the wooden elements. In parallel, we studied the typologies of joints, constructive techniques used, identification of historical tools of manufacture, the documentation of signs and traces that the wood carries, which all talk about the past of the church, the society that generated it and used it. An historical study based on written sources was started, by studying all the archives we found. There was also a session of interpretation of the data collected up to that point from the historical study, dendrocronological analysis, traces and techniques used, in order to obtain an overall interdisciplinary picture of the church. 


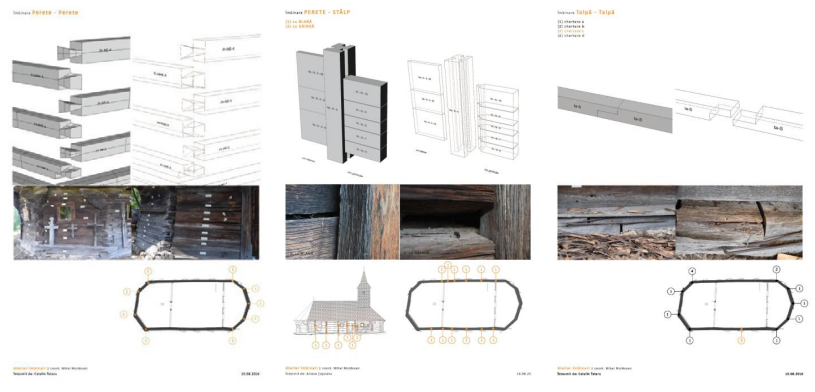

Fig. 8. Typology of joints (original)

We had invited an archeologist who became a part of the project, who made a first archaeological survey inside the church, revealing the old floor layings and their support.
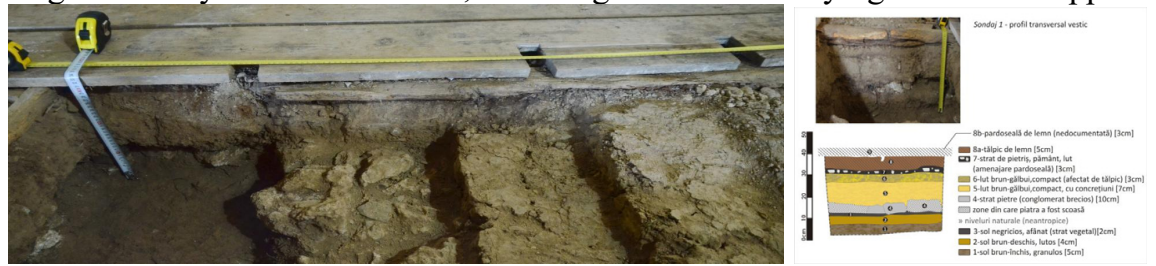

Fig. 9. The archeological survey (original)

Next year (2017), steps were taken to prepare the restoration project to obtain the building permit. For this, necessary studies have been completed (structural expertise, biological, dendrocronological, topographic and geotechnical studies).

The summer restoration workshop of that year was used to bring together the entire project team and to have an interdisciplinary dialogue based on all the discoveries made in the previous years. to correlate them, and to agree on the future interventions needed to restore the church. This meeting was attended by biologist Livia Bucsa, structural engineer Dorottya Makay, our collaborators in the historical study: dr.ing. Bogdan Ilies, PhD. Diana Belci and the mentor of our project dr.arh. Alexandru Baboş. and the architect Bogdan Gogoci and me as the leading architect of the team.

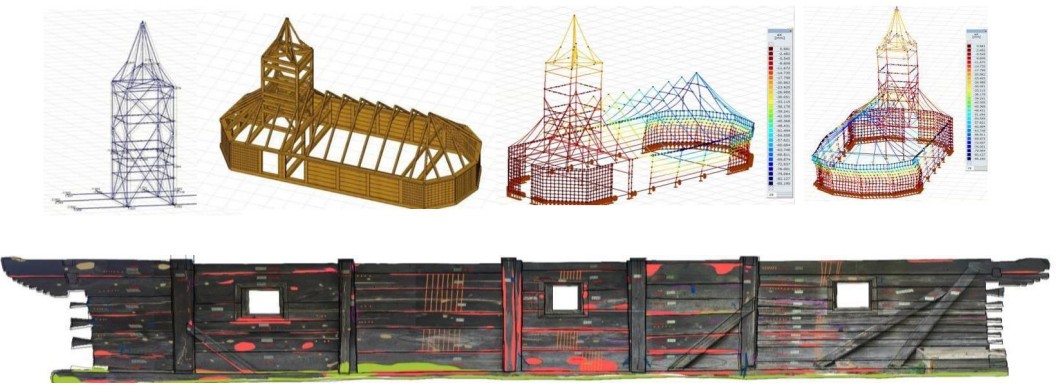

Fig. 10. Putting face to face of the specialties: structural expertise, decay survey, the historical study (original)

The students that participated prepared 3D simulations of the discovered stages through which our wooden church passed.

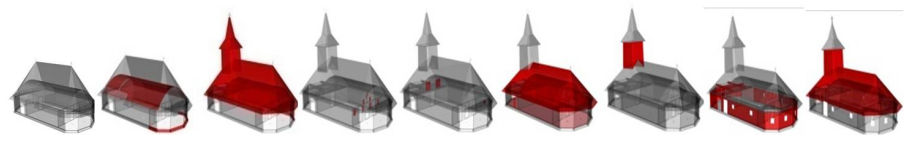

Fig. 11. The historical stages of the wooden church - according to the historical study (original) 


\subsection{The restoration project}

On Feb. 12, 2018, in the vegetative rest period and a decreasing moon, six oac trees were traditional manually cut, necessary to replace the rotten bottom beams of the church. This was the first stage of the restoration project.
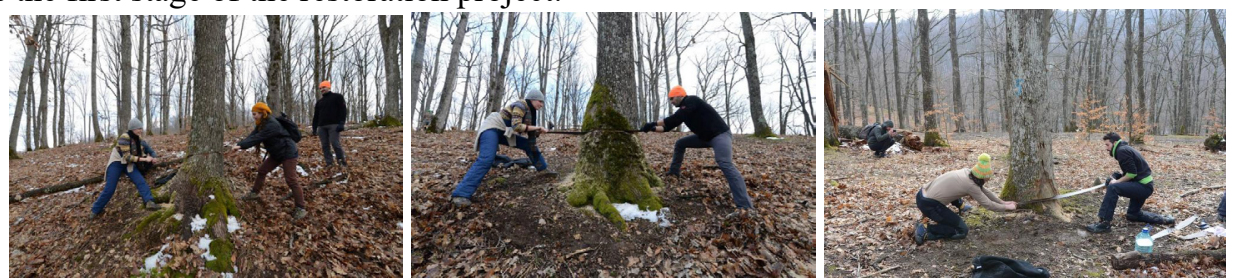

Fig. 12. Traditional oak lumbering (original)

In the summer of 2018, the traditional shingle fabrication was started by "Nicolae" an old cratsman, with which the church is to be covered.

Also the manually oak tree carving started in order to replace the bottom beams of the church by our craftsment team: Toader Nicolae, Ioan Cioara, Florin Lazarescu and Cornel Toader.
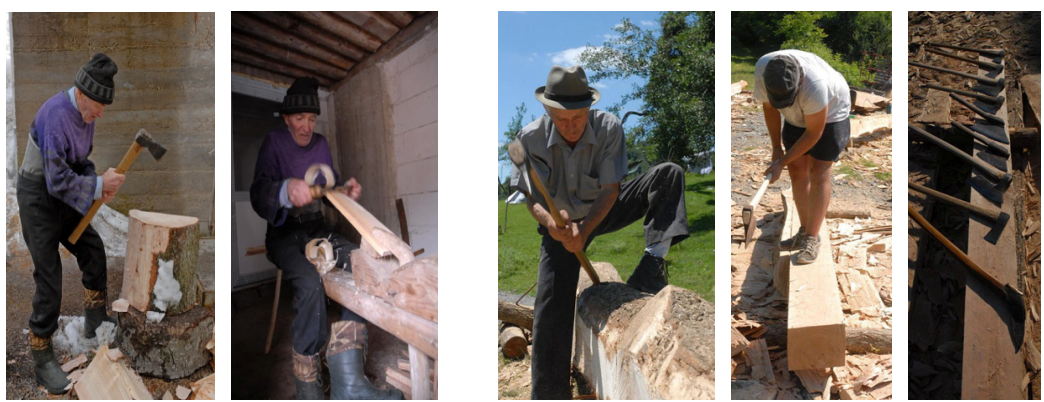

Fig. 13. Traditional shingle cutting / Traditional wood carving (original)

The student workshop in the summer of 2018 was less intense compared to previous years, where exercises were held with the students participating in the understanding of the wooden church, from several perspectives, the restoration project was presented to them and we visited craftsmen from the area who still work traditional crafts such as smiths and carpenters.
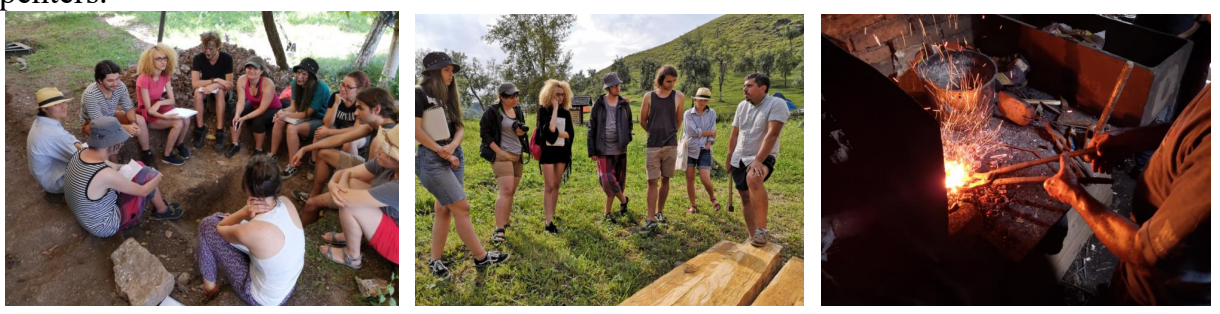

Fig. 14. Heritage related discussions / visiting traditional craftsmen (original)

In September, the third stage of restoration work began, in which the wooden church was raised entirely by means of a stiffening structure, approx. $60 \mathrm{~cm}$ from the initial elevation. Once the church was raised, it was possible to change the bottom beams and work underneath them to build the stone foundations. 

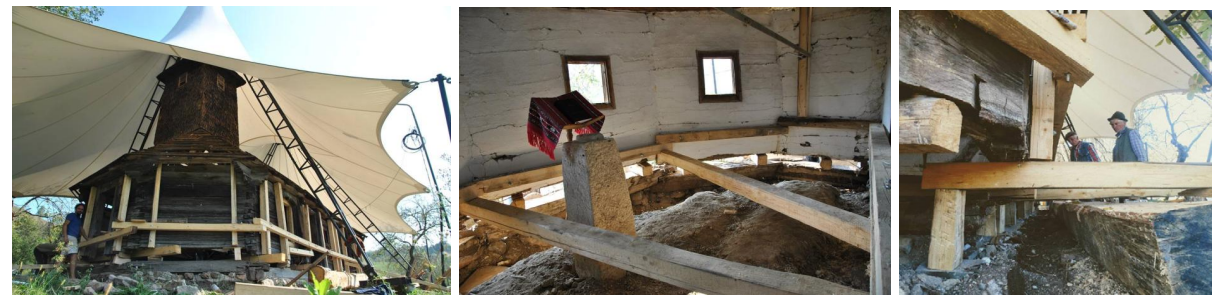

Fig. 15. Raising of the church and replacing of the decayed bottom beams (original)
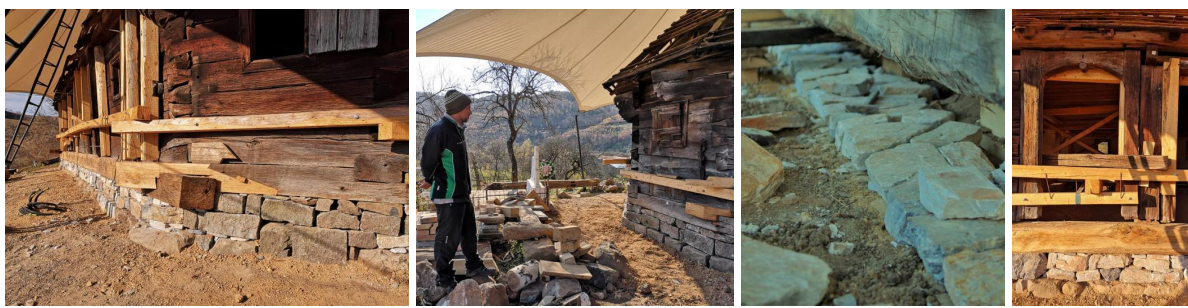

Fig. 16. The replaced bottom beams and the stone foundation (original)

In May-June 2019, the fourth stage of restoration work began, consisting of interventions at the upper part of the church, plumbing and changing of some degraded elements. Also, the rest of the structural reinforcement interventions were caried out, to the wooden vault, at the roof structure and at the tower structure.
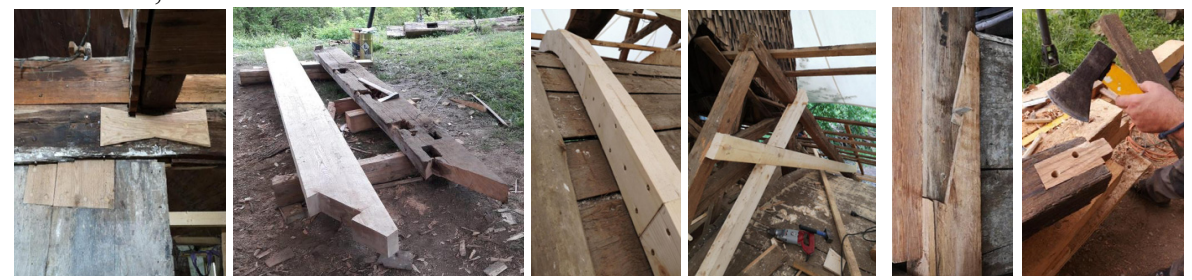

Fig. 17. Lockings / squeles of some decayed structural parts, new structural elements to strengthen the structure (original)

Similar to the project team, the craftsman-restorers become also a craftmanship school, although we have the carpenter Toader Nicolae, a master of wood work, due to the structural complexity of the restoration site, many things are learned by the dialogue, between craftsmen, structural engineers and architects.

The interventions will continue with the shingle roofing, the interior floor reassembling, earth plastering of two interior walls, systematization of the area in the proximity of the church and realising a drain on the northern side.

\section{Conclusion and the next step}

\subsection{Conclusions}

The conclusion of this article is that a similar project can only be carried out in an interdisciplinary team, preferably with working experience between the team members, according to the recommendations of the Venice-Charter [4] and Burra-Charter [5] .

The positive part of this project is that it was a school project where everyone learned along the way and things were approached with caution. It has also been an experimental 
project, in which different research methods have been tried, which, compared, can lead to the adoption of the most useful approaches to future restoration projects.

A self-criticism may be linked to our lack of experience in this area of restoration, which has led to a long time period of the restoration project, and during the restoration site there was a lack of an experienced technical specialist on such interventions to master both the technical part, to understand the restoration project and to have a restoration school in his back. Wood specialists are very few left in Romania, we are confronted with the lack of craftsmen and experts in this area of restoration.

Besides the restoration of the wooden monument church, the purpose of this project is to promote all the work carried out, on our project page https://www.ceva-patrimoniu.ro/ and on the facebook page [6], to involve as many specialists and students in the areas related to the restoration, to create a bigger project team and craftsmen specialized in wood restoration.

Only in the western part of Romania we have left over 300 monument wooden churches, many of which require restoration interventions. [7]

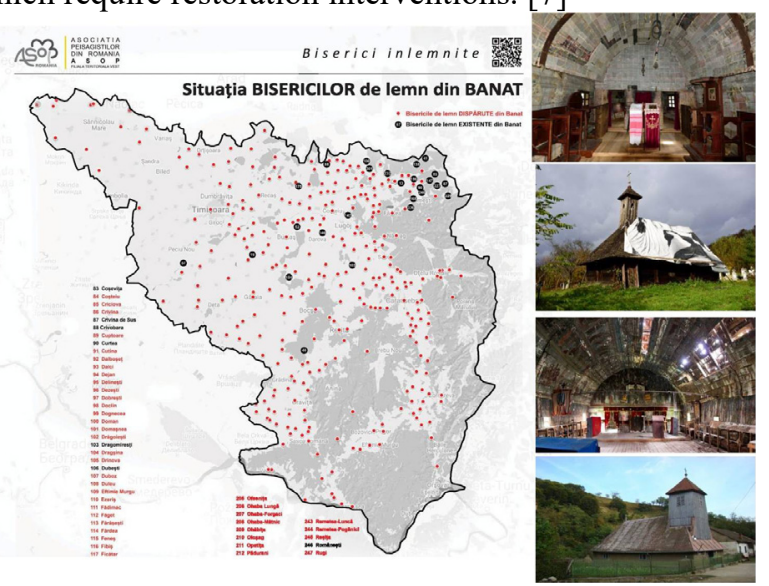

Fig. 18. Past / present situation of wooden churches in Banat region (original + Wikipedia)

\subsection{Next step}

The next objective of the new interdisciplinary team of specialists and craftsmen is the beginning of the studies, the restoration project and the intervention for the wooden monument church "Sfintii Arhangeli Mihail si Gavril" in the town of Povergina, which partially burned in 2016 .

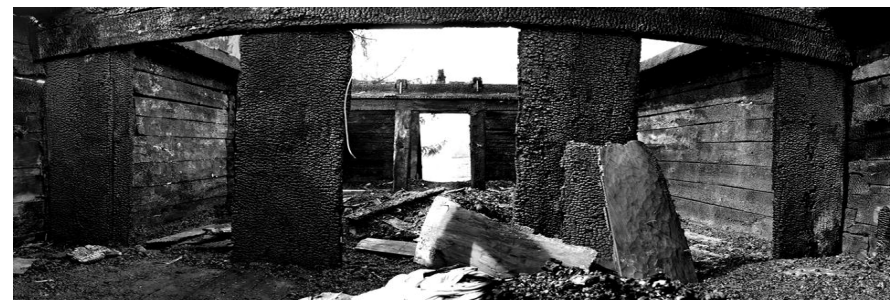

Fig. 19. next step: a future project for the interdisciplinary team, the burnt monument church " Saints Archangels Michael and Gavriil " Povergina village (original) 


\section{References}

1. A. Ciobotă, R. Rusu, A. Condoroș, V. Obradovici, Cimitirul ca element în evoluția peisajului cultural; Recomandări de protecție a caracterului etnic în cimitirele rurale românești, sârbești și ucrainiene din Banat, Ed.Învierea, Timişoara, (2013)

2. T.O. Gheorghiu, Locuirea Tradițională Rurală din zona Banat-Crișana. Elemente de Istorie și Morfologie ; Protecție și Integrare, Ed. DTP Express, Timişoara (2008)

3. https://ro.wikipedia.org/wiki/Biserica_de_lemn_din_Crivina_de_Sus

4. ${ }^{*} \mathrm{https}: / /$ www.icomos.org/charters/venice_e.pdf

5. https://australia.icomos.org/wp-content/uploads/The-Burra-Charter-2013-Adopted31.10.2013.pdf

6. https://www.facebook.com/bisericinlemnite/

7. https://ro.wikipedia.org/wiki/Biserici_de_lemn_din_Banat 